\title{
The EVES motif mediates both intermolecular and intramolecular regulation of $\mathbf{c}-\mathrm{Myb}$
}

\author{
Ajeeta B. Dash, Frank C. Orrico, and Scott A. Ness ${ }^{1}$ \\ Northwestern University, Department of Biochemistry, Molecular Biology and Cell Biology, Evanston, Illinois 60208-3500 \\ USA
}

The c-Myb transcription factor is a proto-oncoprotein whose latent transforming activity can be unmasked by truncation of either terminus. Because both ends of Myb are involved in negative regulation, we tested whether they could associate in a two-hybrid assay and identified a carboxy-terminal motif that interacts with the amino-terminal DNA-binding domain. The EVES motif is highly conserved in vertebrate c-Myb proteins and contains a known site of phosphorylation previously implicated in the negative regulation of $\mathrm{c}-\mathrm{Myb}$. Interestingly, a related EVES motif is present in p100, a ubiquitously expressed transcriptional coactivator found in diverse species. We show that p100 interacts with and influences the activity of c-Myb, implicating it in the regulation of $\mathbf{c}-\mathrm{Myb}$, differentiation, and cell growth. Our results suggest that Myb is regulated by a novel mechanism in which intramolecular interactions and conformational changes control the intermolecular associations among $M y b, \mathbf{p 1 0 0}$, and the transcriptional apparatus.

[Key Words: Transcription; protein interactions; cofactors; oncoproteins; negative regulation]

Received May 2, 1996; revised version accepted June 26, 1996.

Transforming retroviruses are tumorigenic because they have transduced activated versions of proto-oncogenes, the regulators of growth and differentiation in normal cells (Bishop 1991). Some proto-oncogenes, such as c-src and $c-m y c$, can transform cells if sufficiently overexpressed. For others, like c-ras, c-jun, and c-myb, activating mutations are required to unmask the full transforming potential of the proteins. Activated versions of $c-m y b$ have been transduced independently by two different avian leukemia viruses, avian myeloblastosis virus (AMV) and E26, both of which transform immature hematopoietic cells in vitro and induce acute myeloid leukemias in birds. Activation of the c-myb gene by retrovirus insertion has been linked to tumor formation in mammals (Shen-Ong et al. 1986; Mukhopadhyaya and Wolff 1992; Nason-Burchenal and Wolff 1993), and ectopic overexpression of full length $\mathrm{c}-\mathrm{Myb}$ blocks the induced differentiation of hematopoietic cells in tissue culture /Clarke et al. 1988; Todokoro et al. 1988; McClinton et al. 1990; Yanagisawa et al. 1991; Selvakumaran et al. 1992; Smarda and Lipsick 1994; Bies et al. 1995 ), suggesting that $\mathrm{c}-\mathrm{Myb}$ plays a role in maintaining the undifferentiated, proliferating state of the immature cells.

The c- and v-Myb proteins share a common DNAbinding domain motif that resembles two or three concatenated homeo domains (Frampton et al. 1989; Ogata et al. 1993, 1994). This structure has been conserved in

\footnotetext{
${ }^{1}$ Corresponding author.
}

related DNA-binding proteins from animals, plants, and fungi (for review, see Ness 1996; Ramachandran et al. 1994), as well as in two other animal proteins, A-Myb and B-Myb (Nomura et al. 1988). All of these proteins are transcription factors that presumably regulate the expression of genes important for cell growth and differentiation. Although a number of potential Myb-regulated genes have been identified (for review, see Ness 1996), none has been definitively linked to Myb's ability to transform cells or induce leukemias.

Numerous experiments have demonstrated that truncation leads to activation of the $\mathrm{c}-\mathrm{Myb}$ protein. For example, both forms of $\mathrm{v}-\mathrm{Myb}$ are truncated at the ends, and only truncated versions of $c-M y b$ are able to efficiently transform cells or to induce tumors in animals (Gonda et al. 1989a,b; Grässer et al. 1991; Ferrao et al. 1995). Ectopic overexpression of full-length $c-m y b$ in transgenic mice leads to numerous abnormalities but does not induce tumors or leukemias (Furuta et al. 1993). Interestingly, analyses of tumors with activated c-myb genes suggest that the protein's transforming activity can be partially unmasked by removal of either end (Shen-Ong et al. 1984, 1986; Gonda et al. 1989a; Hu et al. 1991), and in vitro experiments have confirmed that both termini contribute to negative regulation (Ramsay et al. 1991; Dini and Lipsick 1993; Nomura et al. 1993; Dini et al. 1995). The complex nature of c-Myb suggests that multiple mechanisms may influence its activity. For example, regulatory phosphorylation sites have been identified near both the amino and carboxyl termini of $\mathrm{c}-\mathrm{Myb}$ 
(Lüscher et al. 1990; Aziz et al. 1993, 1995; Oelgeschläger et al. 1995), and several regions of the protein have been implicated in interactions with potential regulators (Dubendorff et al. 1992; Kanei-Ishii et al. 1992; Nomura et al. 1993; Favier and Gonda 1994; Vorbrueggen et al. 1994).

Although many different experiments have confirmed that the termini of c-Myb inhibit its activity, little is known about how this negative autoregulation is actually mediated. Using a combination of protein interaction assays in yeast cells and in vitro, we show that a novel intramolecular mechanism regulates c-Myb activity. We propose that the carboxy-terminal negative regulatory domain in c-Myb "folds back" to bind to the protein's amino-terminal DNA-binding domain. This regulation depends on a protein interaction motif that contains a previously identified regulatory phosphorylation site. Furthermore, the motif is shared by both the c-Myb negative regulatory domain and a ubiquitous coactivator protein that also binds to Myb. Thus, the ability of c-Myb to interact with a cellular cofactor appears to be regulated by competing inter- and intramolecular interactions.

\section{Results}

\section{The two ends of $c-M y b$ interact in yeast}

Numerous studies have suggested that both ends of the c-Myb protein are involved in negative autoregulation of its activity. We hypothesized that this regulation could be mediated by a direct interaction between the aminoand carboxy-terminal ends of the protein and tested this using the yeast two-hybrid or interaction trap system (Fields and Song 1989; Zervos et al. 1993). Briefly, a "bait" molecule was constructed that fused the aminoterminal 192 amino acids of chick c-Myb to the DNAbinding domain of the Escherichia coli LexA protein (Fig. 1A,B). The resulting LexA-Myb192 construct was able to bind to LexA operators, but lacked inherent transactivation activity, and failed to induce the expression of the LexA operator-dependent LEU2 or lacZ reporter genes on its own (Fig. 1C; data not shown). The LexAMyb192 bait was tested with a number of target proteins expressed from plasmid pJG4-5, a yeast vector designed to express recombinant proteins fused to a nuclear targeting signal and an epitope tag (Gyuris et al. 1993). Interaction between the two expressed proteins is detected by following the induction of the $L E U 2$ and $l a c Z$ reporter genes, which confer the ability to grow on leucine-deficient medium or to accumulate $\beta$-galactosidase activity (blue color on X-gal medium), respectively.

Interestingly, the LexA-Myb192 protein interacted with fusion proteins derived from the carboxy-terminal regions of c-Myb. As shown in Figure $1 \mathrm{C}$, the yeast reporter strain did not grow on leucine-deficient medium when LexA-Myb192 was coexpressed with the pJG4-5 vector alone or with a number of other control fusion proteins (Fig. 2; data not shown). However, significant growth on leucine-deficient medium was observed when
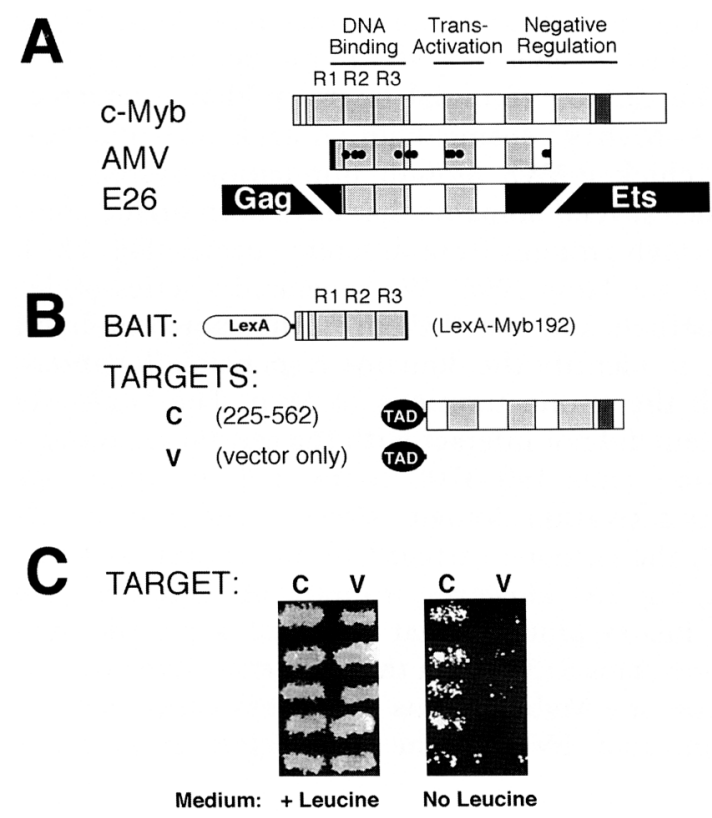

Figure 1. The two ends of c-Myb interact in a two-hybrid assay. (A) Structure and conserved domains in c- and v-Myb proteins. The diagrams depict the primary structures of c-Myb 1642 amino acids) and the v-Myb-containing proteins encoded by the AMV and E26 viruses. The Myb repeats (R1, R2, and $R 3$ ) that constitute the c-Myb-DBD are indicated at the top, as are the domains responsible for trans-activation and negative regulation. Shaded blocks indicate regions of highest conservation between vertebrate $\mathrm{c}-\mathrm{Myb}$ proteins. Non-Myb regions of the viral proteins (not drawn to scale) are shaded black. These include 6 and 272 amino-terminal amino acids derived from Gag in the AMV and E26 proteins, respectively, plus the 491 carboxy-terminal amino acids of $\mathrm{v}$-Ets, which are E26-specific. The 11 AMV-specific point mutations are indicated by dots. $(B)$ Twohybrid assay constituents. (BAIT) An amino-terminal fragment of the chick c-Myb cDNA was transferred to the yeast vector pEG202. The resulting plasmid expressed a fusion protein (LexA-Myb192) composed of 202 and 192 amino acids derived from LexA and c-Myb, respectively, and containing the DNAbinding domains of each. (TARGETS) A fragment from the c-Myb cDNA encoding amino acids 225-562 was transferred to the yeast expression vector pJG4-5, resulting in expression of the c-Myb peptide fused to the combination of an epitope tag, nuclear targeting signal, and trans-activation domain (indicated by TAD|, under the control of the inducible GAL1 promoter. The pIG4-5 vector without an insert served as a negative control. (C) Results. The bait and target plasmids described above were introduced into the yeast strain EGY48, which contains an integrated LEU2 reporter gene under the control of six LexA operators. The results with five independent colonies containing the LexA-Myb192 bait expressed with either the carboxyterminal fragment from c-Myb (target $\mathrm{C}$ ) or the vector control (target V) are shown. The yeast strains were replica-plated onto nonselective medium containing leucine or selective medium without leucine, as indicated. Growth on leucine-deficient medium requires induction of the $L E U 2$ gene and indicates that the bait and target proteins interact. Similar results were obtained using the LexA-inducible lacZ reporter gene on plasmid pSH1834 (not shown). 
LexA-Myb192 was coexpressed with target proteins containing the carboxy-terminal region of c-Myb, suggesting that the two ends of Myb can interact in trans (Fig. 1C).

The carboxy-terminal fragment that interacted with LexA-Myb192 spanned amino acids 225-562 (based on the chick c-Myb protein numbering system) and included several domains that have been highly conserved in c-Myb proteins from different species (Fig. 1A; for review, see Ness 1996). We generated a series of deletion constructs and tested them in the same two-hybrid assay, to identify the domains responsible for interacting with the amino terminus of Myb. The LexA-Myb192 protein did not interact with the central region of $\mathrm{c}-\mathrm{Myb}$ (amino acids 190-370), containing the transcriptional trans-activation domain (Weston and Bishop 1989) or with the extreme carboxyl terminus (amino acids 562642 ; Fig. 2A). However, it interacted efficiently with all the fusion proteins that included a peptide spanning amino acids $513-563$ in the chicken $c-M y b$ protein. This region of c-Myb contains the highly conserved string of amino acids EVES (in the single-letter amino acid code),

Figure 2. Two interacting domains of c-Myb. $(A)$ Interaction domains in c-Myb. The structures of the c-Myb and AMV $\mathrm{v}-\mathrm{Myb}$ proteins are illustrated at the top. Two-hybrid interaction assays were performed as described in Fig. 1. Baits contained the c-Myb or AMV DNA-binding domains fused to LexA. Targets had the indicated carboxy-terminal domains from c-Myb fused to an epitope tag, nuclear targeting signal, and trans-activation domain (TAD). Numbers indicate the c-Mybderived amino acids included in each construct. $(+\mid$ The bait and target interact, as judged by growth on leucine-deficient medium and induction of $\beta$-galactosidase activity (blue colonies on X-gal plates). (See Materials and methods for details.) (B) Domains in c-Myb interact efficiently. Two-hybrid assays in yeast were performed as described above and in Fig. 1, except that extracts prepared from log-phase cultures of yeast were assayed for $\beta$-galactosidase activity in solution using a calorimetric assay. The results, given in arbitrary units normalized for protein concentration, are shown at right. The bait and target proteins are described above. The positive control was plasmid pSH17-4, which encodes a protein with the LexA DNAbinding domain fused directly to an acidic trans-activation domain. $|C|$ The interactions are Myb-specific. The yeast twohybrid assay was reversed by expressing a bait construct having a carboxy-terminal fragment from $\mathrm{c}-\mathrm{Myb}$ fused to the LexA DNA-binding domain. The target proteins included the indicated regions from the amino terminus of c-Myb or AMV $\mathrm{v}-\mathrm{Myb}$, or a full-length, intact version of AMV v-Myb protein (see text for details). Assays, plasmids, and results are as described above. which forms a recently identified phosphorylation site involved in negative regulation (Aziz et al. 1995). For simplicity, we will refer to this region of $\mathrm{c}-\mathrm{Myb}$ as the EVES domain.

\section{The EVES domain interacts with the DNA-binding domain of $M y b$}

The initial two-hybrid results described above demonstrated that the conserved EVES domain can interact with the amino-terminal 192 amino acids of c-Myb. We next tested whether the carboxy-terminal domains of c-Myb could also interact with a bait molecule derived from the AMV v-Myb protein. As shown in Figure 2A, the LexA-AMV protein contains amino acids 72-192 of c-Myb, a region that has been defined as the minimum DNA-binding domain of Myb (Myb-DBD) (Howe et al. 1990; Garcia et al. 1991). However, the AMV version also contains several point mutations that enhance its transforming activity (Introna et al. 1990; Dini et al. 1995). Interestingly, the LexA-AMV protein interacted

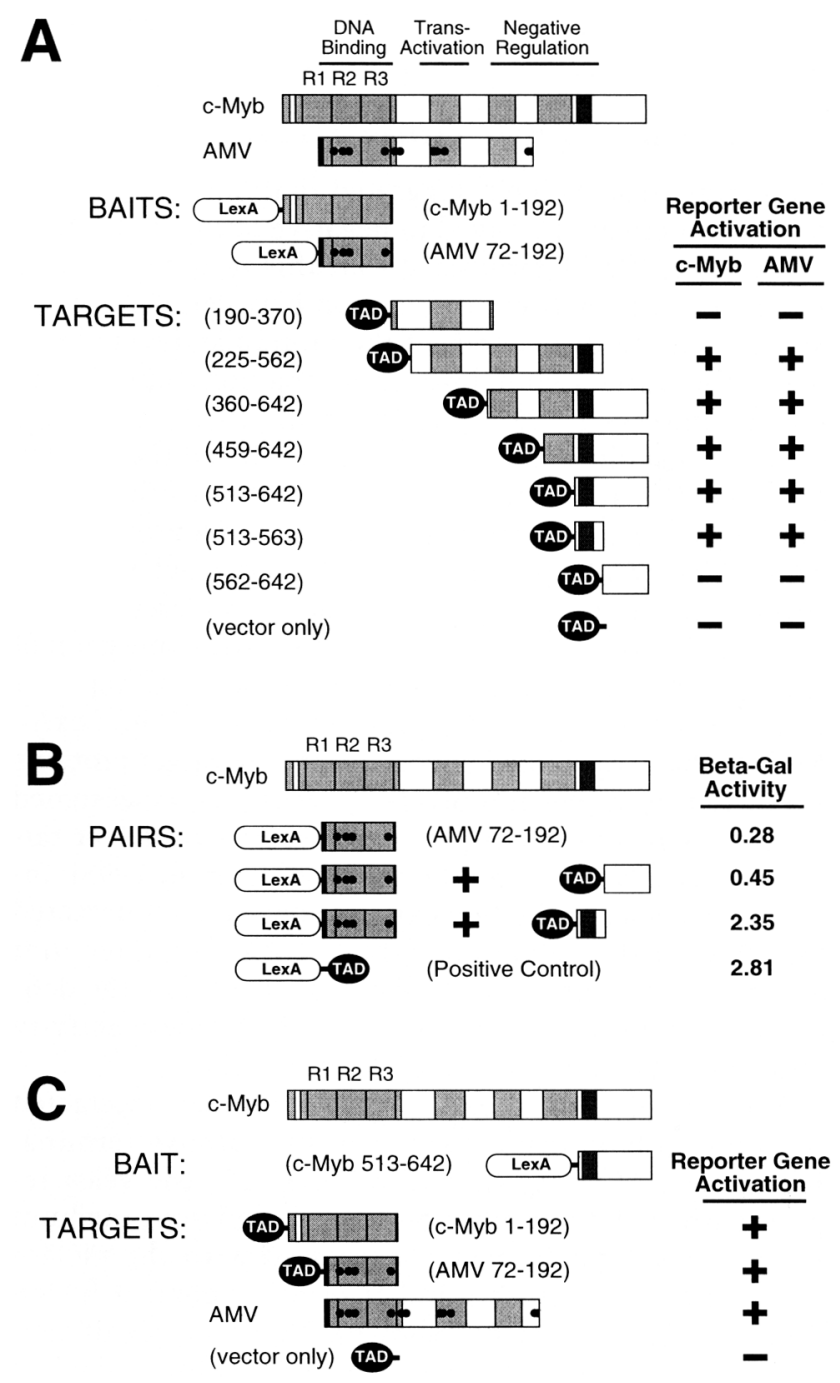


efficiently with the fusion protein targets containing the EVES domain (Fig. 2A), indicating both that the AMVspecific point mutations do not disrupt the ability of the two ends of Myb to interact and that amino acids 72-192 of Myb are sufficient for the interaction with the EVES domain.

Although two-hybrid system results can be difficult to correlate with biochemical measurements of protein affinity, they can provide qualitative estimates of interaction strengths (Estojak et al. 1995). As shown in Figure $2 B$, only a background level of $\beta$-galactosidase activity was expressed by yeast strains expressing the LexAAMV bait either by itself or coexpressed with portions of c-Myb lacking the EVES domain. However, the combination of LexA-AMV plus target proteins containing the EVES domain induced high levels of $\beta$-galactosidase activity, comparable to the levels induced by the positive control (LexA fused directly to a strong trans-activation domain). Although these data do not allow us to estimate protein affinities, they do suggest that the EVES domain interacts fairly efficiently with the Myb-DBD.

As a further control, the two-hybrid assay was reversed so that the EVES domain became the bait. A LexA fusion protein derived from the carboxyl terminus of $\mathrm{c}-\mathrm{Myb}$ and containing the EVES domain interacted efficiently with Myb192, the amino-terminal 192 amino acids of Myb expressed in plasmid pJG4-5 (Fig. 2C). It also interacted efficiently with an intact AMV v-Myb-transforming protein expressed from a yeast expression plasmid. The latter protein spans amino acids $72-436$ of c-Myb, including the DNA-binding and trans-activation domains but lacks the extreme amino terminus of c-Myb as well as the carboxy-terminal negative regulatory region and the EVES domain. Furthermore, it contains no amino acids derived from LexA or the expression vectors. This rules out the possibility that either the introduced nuclear targeting signals or epitope tags contributed by the twohybrid system expression vectors could be playing significant roles in the observed interactions and demonstrates that the EVES domain can interact with an intact $\mathrm{v}-\mathrm{Myb}$-transforming protein.

A coimmunoprecipitation assay was used as an independent analysis of the interaction between the two ends of Myb and to verify that the two termini could physically associate in yeast. Briefly, extracts were prepared from control yeast cells or yeast expressing the intact AMV v-Myb protein, either alone or with an hemagglutinin (HA) epitope-tagged version of the EVES domain (Fig. 3). In Western blots of whole cell lysates (Fig. 3, lanes 1-6), the HA-EVES protein was detected with HA epitope-specific antibodies (Fig. 3, lane 2) and the AMV v-Myb protein with anti-Myb antibodies (Fig. 3, lanes 4,5 ). To test for interaction, similar samples were first subjected to immunoprecipitation with anti-Myb or preimmune antisera, and the resulting precipitates were analyzed by Western blotting. The AMV v-Myb protein was efficiently immunoprecipitated with antiserum specific for the Myb-DBD, but not with control, preimmune serum (Fig. 3, cf. lanes 9 and 10 with 13 and 14). The HA-EVES protein was coisolated with Myb, but

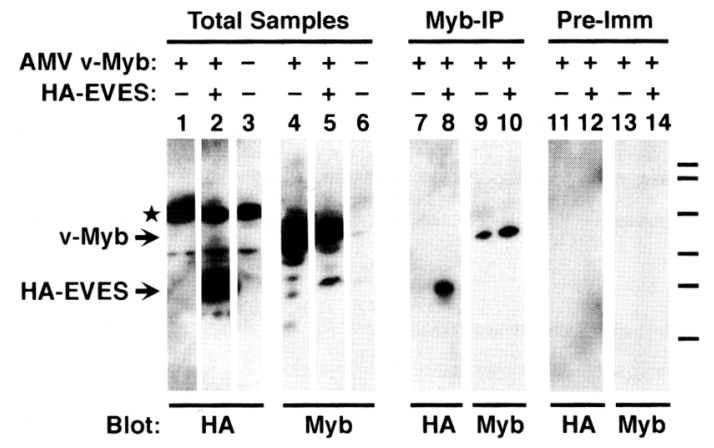

Figure 3. The termini of $c-M y b$ form a complex in solution. Whole-cell extracts were prepared from control yeast (lanes 3,6) or from yeast cells expressing AMV $\mathrm{v}-\mathrm{Myb}$ alone flanes $1,4,7,9,11,13$ ) or together with the HA-EVES protein spanning amino acids $513-642$ of chick c-Myb (lanes 2,5,8,10,12,14), as indicated at the top. The extracts were analyzed directly [(Total Samples) lanes 1-6] or after immunoprecipitation with antisera specific for the Myb-DBD [(Myb-IP) lanes 7-10] or pre-immune control serum [(Pre-Imm) lanes 11-14]. The crude extracts or immunoprecipitates were analyzed by Western blotting using monoclonal antibodies directed against the HA epitope tag [Blot (HA) lanes 1-3,7,8,11,12); or the Myb-DBD [Blot: (Myb) lanes $4-6,9,10,13,14]$ as indicated at the bottom. The migration of the $\mathrm{v}-\mathrm{Myb}$ and HA-EVES proteins are indicated at the left. The star indicates the migration of an HA antibody-reactive yeast protein detected in all total extracts. Horizontal, black bars on the right indicate the migration of prestained molecular weight markers [(Bio-Rad) from top]: 112,$000 ; 84,000 ; 53,200 ; 34,900 ; 28,700$; 20,500.

only when Myb-specific antiserum was used for the immunoprecipitation (Fig. 3, lane 8). It was not immunoprecipitated by control antisera (Fig. 3, lane 12) and was not detected in extracts from yeast expressing Myb by itself (Fig. 3, lanes 1,7,11), ruling out that the immunoreactivity was attributable to contaminating yeast proteins. We conclude that the Myb-DBD and EVES domain interact directly, by forming a stable complex in eukaryotic cells.

\section{The EVES domain is highly conserved in $c-M y b$ proteins}

The results described above demonstrate that the EVES domain mediates interactions between the two ends of Myb, implicating it in the negative regulation of the protein. The EVES domain is found in all vertebrate $c-M y b$ proteins: 16 of 25 residues around the EVES sequence are identical in c-Myb proteins from humans, mice (which have AVES rather than EVES), chickens, and frogs (Fig. 4A). Two-hybrid analyses confirmed that the EVES domain from the Xenopus protein also interacted with the c-Myb-DBD (data not shown). This result is quite significant and has several implications. First, it suggests that the intramolecular interactions that we have detected have been conserved in Myb proteins from species as diverse as mammals and amphibians, suggesting that they are important for the function of the protein. Sec- 
A

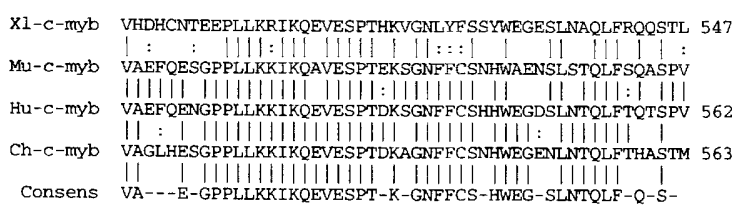

B

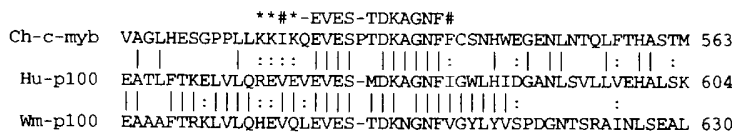

Figure 4. The EVES domain is conserved in c-Myb and p100. (A) Comparison of EVES domains from $X$. laevis (amino acids 497-547, Xl), mouse (amino acids 466-516, Mu), human (amino acids $512-562, \mathrm{Hu}$ ), and chicken (amino acids 513-563, Ch) c-Myb proteins (GenBank accession nos. L22741, M12848, M15024, and M14129, respectively). The most highly conserved positions are shown at the bottom (Consens). (B) Comparison of EVES domains from chicken c-Myb (Ch-c-myb; amino acids 513-563), the human transcriptional coactivator pl00 $(\mathrm{Hu}-$ p100; GenBank accession no. U22055; amino acids 555-604), and a related C. elegans gene product $(\mathrm{Wm}-\mathrm{pl00}$; GenBank accession no. U40029; predicted gene product F10G7.2; amino acids 581-630). The latter two proteins were identified using the BLAST program as described in Materials and methods. The most highly conserved amino acids are shown at the top, with conserved charged ( $)$ and hydrophobic $(\#)$ residues.

ond, the most highly conserved amino acids in this region are most likely to be involved in the interaction with the amino terminus. The conserved amino acids define an $\sim 25$ amino acid long consensus motif that might also be found in other Myb-binding proteins.

\section{A transcriptional coactivator contains a functional EVES domain}

Several studies have suggested that cellular proteins interact with the Myb-DBD (Introna et al. 1990; Dini et al. 1995). We speculated that other Myb-binding proteins might have a domain related to EVES and, therefore, compared the chicken c-Myb EVES domain sequence (amino acids 513-563) to all entries in the protein sequence libraries available at the National Center for Biotechnology Information (NCBI), using the BLAST network service (Altschul et al. 1990). The most related non-Myb protein detected by this method is p100, a recently characterized, $100-\mathrm{kD}$ transcriptional coactivator, originally identified in Epstein-Barr virus (EBV)-transformed B cells. The p100 protein binds to EBNA-2, a transcription factor encoded by EBV, as well as the RNA polymerase II initiation factor TFIIE (Tong et al. 1995). An open reading frame from the nematode Caenorhab. ditis elegans (cosmid F10G7.2) is predicted to encode a p100-related protein that also has an EVES domain (Fig. $4 \mathrm{~B})$. Thus, the EVES domain has been conserved in c-Myb proteins and putative transcriptional cofactor proteins from diverse species.

The identification of potential EVES domains in pro- teins known to be transcriptional coactivators prompted us to test whether the EVES domain of human p100 could interact with Myb. As shown in Figure 5, the EVES domain at amino acids 545-609 of the human pl00 protein interacted efficiently in a two-hybrid assay with both the c-Myb and AMV v-Myb-DBDs but not with control proteins. These results suggest that the EVES domain mediates interactions between Myb proteins and the p100 transcriptional coactivator.

\section{Full-length Myb and $p 100$ proteins interact}

The experiments described above demonstrated that the isolated EVES domain from the pl00 protein could interact with Myb. We used an indirect immunoprecipitation assay to eliminate the influence of extraneous yeast proteins or other components of the two-hybrid system, and to test whether intact and full-length p100 and Myb proteins would associate. Full-length, ${ }^{35} \mathrm{~S}$-labeled human pl00 protein was synthesized in vitro, using an expression vector that resulted in production of the pl00 protein fused to an amino-terminal FLAG epitope tag (Tong et al. 1995). First, to rule out that other proteins participated in the pl00-Myb complex, the recombinant p100 protein was incubated with a highly purified, bacterialexpressed fragment of the chicken c-Myb protein that spanned amino acids 72-192, the minimal DNA-binding domain. After a brief incubation, protein complexes were isolated by immunoprecipitation using antisera specific for the Myb-DBD or the FLAG epitope tag in p100. Preimmune antiserum was used in parallel as a negative control. The resulting immunoprecipitates were analyzed by SDS-polyacrylamide gel electrophore-

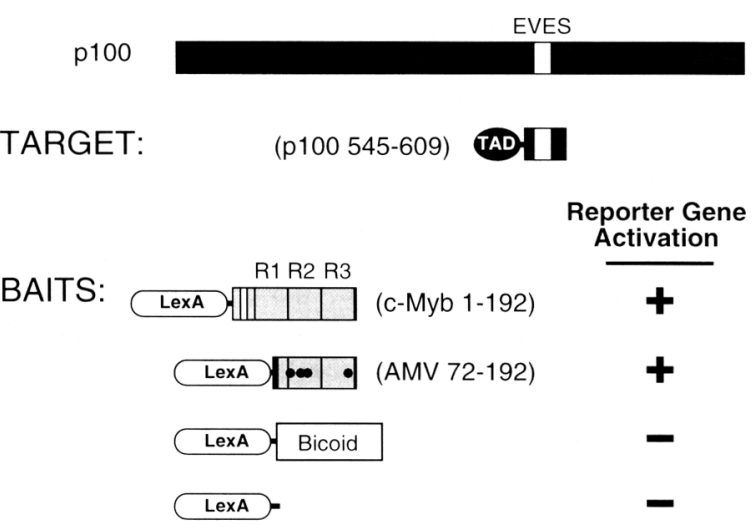

Figure 5. The EVES domain from pl00 interacts with Myb in yeast. The EVES domain from human pl00/GenBank accession no. U22055; amino acids 545-609) was transferred to the yeast two-hybrid target vector pJG4-5 and then tested as described in Figs. 1 and 2. Bait plasmids expressed LexA fused to the DNAbinding domains of c-Myb or AMV v-Myb (see Fig. 2), a transcriptionally inactive region of the Drosophila melanogaster Bicoid protein (amino acids 2-160, plasmid pRFHM1) or the vector pEG202 (LexA) alone. Positive interaction was scored as growth on leucine-deficient medium and by induction of $\beta$-galactosidase activity as described in Figs. 1 and 2. 
sis, and the radiolabeled p100 protein was detected by fluorography or autoradiography.

The anti-FLAG epitope tag-specific antiserum effectively immunoprecipitated the in vitro-translated p100 protein, whereas only background levels were recovered when either preimmune or anti-Myb antisera were used (Fig. 6, lanes 1-3). However, both the anti-FLAG and anti-Myb antisera immunoprecipitated p100 when purified, recombinant Myb protein was added (Fig. 6, lanes $5,6)$. Control experiments verified that the anti-FLAG antiserum did not cross-react with Myb (data not shown). In addition, the preimmune serum still immunoprecipitated only background levels of p100 (Fig. 6, lane 4), ruling out that the addition of bacterial-expressed Myb protein increased the recovery of the p100 through a nonspecific mechanism. A similar result was obtained when the experiment was repeated using a partially purified human c-Myb preparation derived from Jurkat T-cell nuclear extracts (Fig. 6, lanes 7-9). Again, although the preimmune serum gave only background levels of p100, both the anti-FLAG and anti-Myb antisera were effective at immunoprecipitating the radiolabeled p100 protein. The anti-Myb antiserum was unable to immunoprecipitate a mutant form of p100 lacking the EVES domain (amino acids 545-609; Fig. 6, lanes 10-12). Thus, anti-Myb antisera can immunoprecipitate p100 only when c-Myb is present and only when the p100 EVES domain is intact. We conclude that the EVES domain mediates the formation of a stable complex between c-Myb and plo0.

\section{p100 affects Myb activity}

The experiments described above demonstrated that

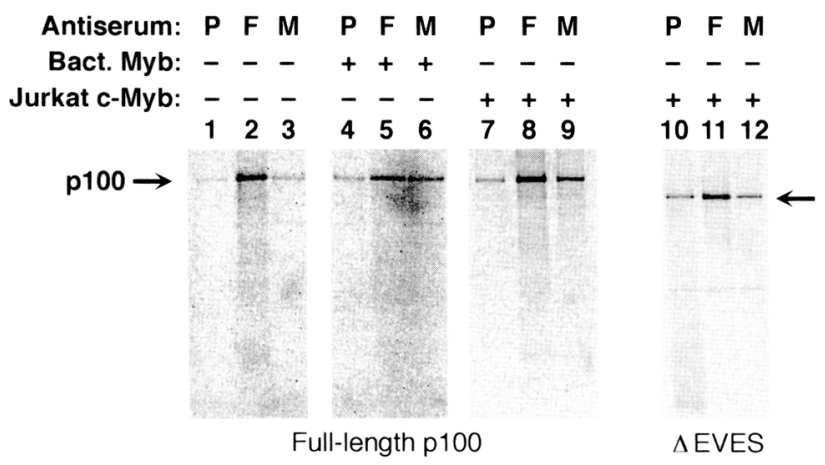

Figure 6. Myb and p100 proteins interact in vitro. An in vitro transcription/translation system was used to generate fulllength (lanes 1-9) or mutant (AEVES, lanes 10-12) ${ }^{35}$ S-labeled human p100 proteins with an incorporated amino-terminal FLAG epitope tag. The samples were mixed with control extracts (lanes 1-3), purified, bacterially expressed c-Myb-DBD (lanes 4-6), or a c-Myb-enriched nuclear extract from human Jurkat $T$ cells (lanes 7-12). After incubation on ice, pl00 protein was immunoprecipitated using preimmune serum $[(\mathrm{P})$ lanes $1,4,7,10]$, antiserum directed against the incorporated FLAG epitope tag $[(\mathrm{F})$ lanes 2,5,8,11], or Myb-specific antiserum [(M) lanes $3,6,9,12]$. The immunoprecipitates were washed under stringent conditions and analyzed as described in Materials and methods. p100 could interact with c-Myb and v-Myb proteins, but did not address whether it functioned in Myb-regulated gene expression. A cotransfection assay was used to determine whether ectopic overexpression of p100 would influence transcriptional activation by c-Myb. Briefly, QT6 (quail fibroblast) cells were transfected with a reporter gene derived from the chicken mim-1 gene promoter, with or without expression vectors for $\mathrm{p} 100$ and c-Myb. In addition, all samples included a plasmid expressing NF-M, the avian version of C/EBP $\beta$ or NF-IL6 that cooperates with Myb to fully activate the mim-1 promoter (Ness et al. 1989, 1993; Burk et al. 1993).

The mim-1 promoter showed only modest activity in the absence of Myb but was strongly induced when the cells were transfected with a c-Myb expression plasmid (Fig. 7). Interestingly, additional expression vector plasmid (without an insert) had no effect on the ability of c-Myb to activate the promoter or on the basal level of promoter activity observed in the absence of Myb. However, the plasmid expressing p 100 had a significant effect on Myb activity, resulting in a marked reduction in mim-1 promoter activity. Interestingly, p100 did not affect the Myb-independent activity of the mim-1 promoter, suggesting that it inhibited the activity of c-Myb. From these data alone we cannot determine whether p100 functions as an inhibitor of c-Myb activity or whether its overexpression inhibits indirectly through titration of a limiting cellular component. Nevertheless, the results suggest that p100 is a specific cellular factor

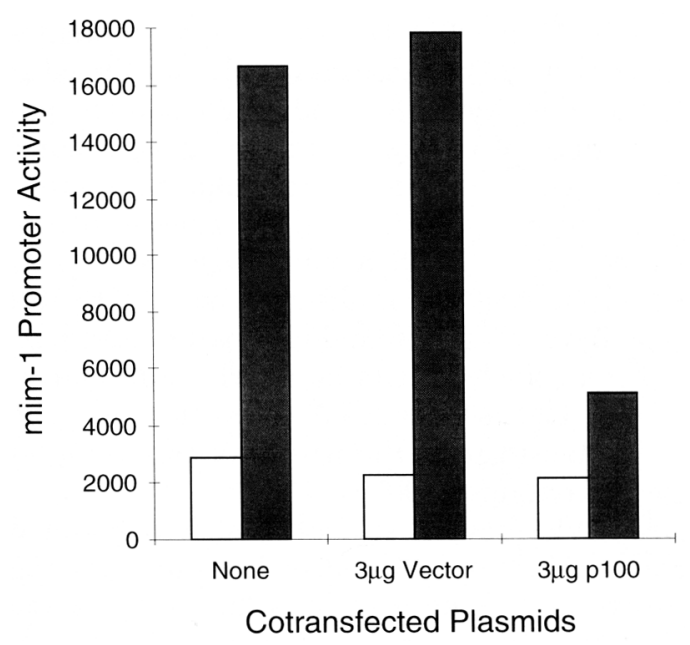

Figure 7. Effect of p100 on Myb activity. QT6 (quail fibroblast) cells were transfected with $0.5 \mu \mathrm{g}$ of a mim-1 promoter-luciferase reporter gene construct plus $0.5 \mu \mathrm{g}$ of an NF-M expression plasmid, using DEAE-dextran. Each sample either did not (open bars) or did (shaded bars) receive $0.5 \mu \mathrm{g}$ of a c-Myb expression vector as well. In addition, some samples received either $1.5 \mu \mathrm{g}$ of the expression vector or $1.5 \mu \mathrm{g}$ of the plasmid expressing human p100, as indicated at the bottom. Cells were harvested 2 days after transfection, and luciferase activities were determined as described in Materials and methods. The average values of duplicate assays are reported. These results are typical of many independent experiments. 
that influences the ability of c-Myb to activate gene expression.

\section{Discussion}

We set out to test a simple hypothesis: Because truncation of either terminus can activate $c-M y b$, negative regulation could be mediated by a direct interaction between its two ends. Using both the yeast two-hybrid system and biochemical assays, we found that the two termini of c-Myb do associate in yeast and that they can form a stable, immunoprecipitable complex mediated by a conserved carboxy-terminal domain containing the sequence EVES. This same sequence has been shown to be a substrate for phosphorylation both in vivo and in vitro, and mutation of this site renders c-Myb more active in trans-activation assays (Aziz et al. 1993, 1995). We have also identified a cellular transcription cofactor that contains a highly related EVES domain, that interacts with c-Myb both in yeast and in vitro, and that modifies the transcriptional activity of c-Myb.

Our data suggest that the EVES domains from Myb and p100 bind directly to the Myb-DBD. This is based on results using yeast two-hybrid assays and reconstitution experiments demonstrating that p100 can interact with purified, recombinant $\mathrm{Myb}-\mathrm{DBD}$ in vitro. We have been unable to demonstrate interactions between the MybDBD and purified, bacterially expressed EVES domains, suggesting that phosphorylation of the latter may be required. We cannot rule out the possibility that the EVES domains interact with an intermediary protein, which could be present in reticulocyte lysate and which in turn binds to the Myb-DBD. However, such a protein would have to be widely expressed and highly conserved among species, as the Myb-DBD and EVES domain proteins from a variety of sources (Jurkat $T$ cells, baculovirusinfected insect cells, rabbit reticulocyte lysates, and yeast) can interact in vitro. We also cannot rule out the possibility that the EVES domain might mediate the formation of head-to-tail multimers of $\mathrm{c}-\mathrm{Myb}$. Interestingly, we have recently found that native $\mathrm{c}-\mathrm{Myb}$ protein isolated from nuclei exists in a high molecular weight complex (J. Leverson and S.A. Ness, unpubl.). We are currently investigating the nature of this complex and whether it contains p100.

Besides EVES, several studies have demonstrated that additional regions of c-Myb also play important negative regulatory roles (Sakura et al. 1989; Bortner and Ostrowski 1991; Grässer et al. 1991; Hu et al. 1991; Dubendorff et al. 1992; Kanei-Ishii et al. 1992; Nomura et al. 1993). Thus, we must conclude that EVES is but one component of a complex domain that regulates $\mathrm{c}-\mathrm{Myb}$ activity. Although the EVES motif is conserved in all vertebrate $\mathrm{c}-\mathrm{Myb}$ proteins, it is not found in the related A-Myb and B-Myb proteins or in Myb-related proteins from insects, fungi, or plants. Thus, if the EVES motif is important for the regulation of $\mathrm{c}-\mathrm{Myb}$, this would imply that the other Myb-related proteins are regulated by distinct mechanisms, which could explain some of the biological differences between the various vertebrate pro- teins, all of which share nearly identical DNA-binding domains and are expressed in overlapping subsets of cells (Golay et al. 1991; Sleeman 1993; Trauth et al. 1994).

\section{A model for $c-M y b$ regulation}

We have shown that the amino and carboxyl termini of the c-Myb protein can interact. This leads to the model for c-Myb regulation shown in Figure 8. In Figure 8A, the EVES domain in p100 mediates an interaction with the Myb-DBD. Because p100 has been shown to interact with both the EBV transcription factor EBNA2, as well as TFIIE, a component of the basal transcription machinery, we speculate that p100 may act as a bridge between Myb and other cellular proteins. In Figure 8B, the EVES domain from the carboxyl terminus of $\mathrm{c}-\mathrm{Myb}$ binds the amino-terminal Myb-DBD, excluding p100, and presumably other cellular proteins as well. Because the transcriptional activity of c-Myb can be activated by introducing a serine to alanine mutation in the $c-M y b$ EVES domain (Aziz et al. 1995), we predict that the MybDBD should preferentially interact with the phosphorylated form of the Myb EVES domain. Phosphorylation
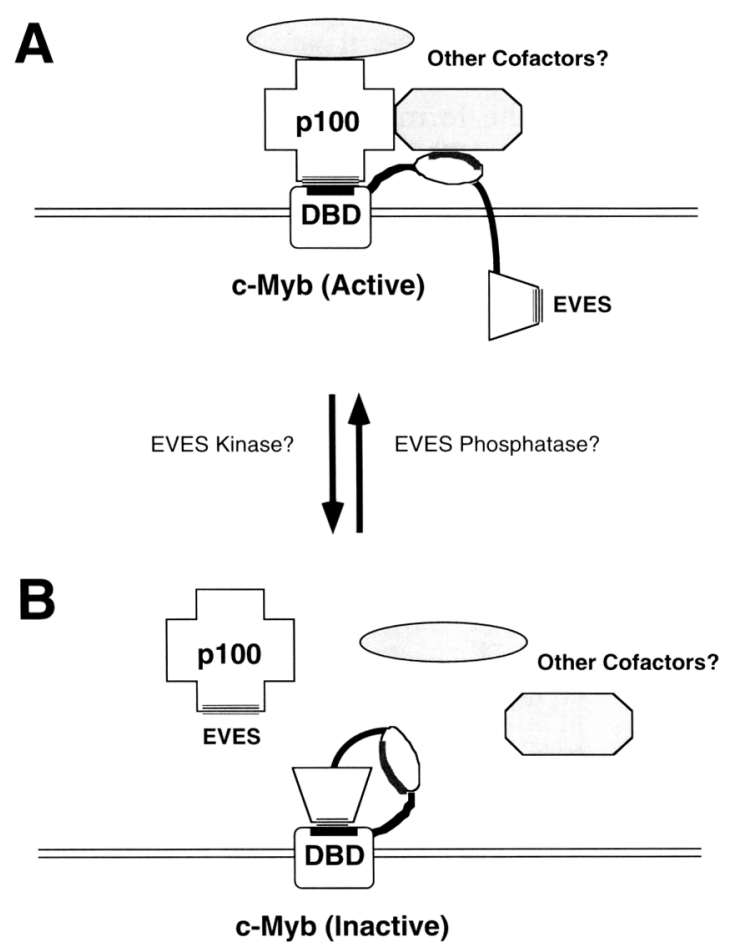

Figure 8. Model for Myb regulation by the EVES domain. $(A)$ The transcriptional coactivator pl00 interacts with the Myb$\mathrm{DBD}$ via its EVES motif. It may mediate interactions between Myb and other cellular proteins. $(B)$ The EVES motif in the carboxy-terminal negative-regulatory domain of c-Myb can interact with the Myb amino terminus. This could displace p100 and associated proteins, in a reaction likely to be regulated by phosphorylation. Note: This model assumes that pl00 is a coactivator, but very similar principles would also apply if it acts as a repressor of Myb. (See Discussion for details.) 
may also affect the ability of the p100 EVES domain to bind c-Myb or to compete with the c-Myb EVES.

Does the EVES domain regulate the DNA-binding activity of c-Myb? Although carboxy-terminal truncations have been reported to increase the DNA-binding activity of $\mathrm{c}-\mathrm{Myb}$, we have been unable to demonstrate a direct effect of p100 or the c-Myb EVES on DNA binding by the Myb-DBD. Unfortunately, the bacterially expressed EVES domains do not bind the Myb-DBD in vitro, probably because they are not phosphorylated. Resolution of this issue will require a detailed understanding of the regulation of p100 binding, an analysis of EVES domain mutants in both c-Myb and p100, and purification of p100, overexpressed EVES domains or the appropriate protein kinases from eukaryotic cells.

Our model implies that c-Myb undergoes large conformational changes, allowing the carboxyl terminus to interact with the amino terminus. This could block the binding of DNA, affect interactions between c-Myb and other proteins, or both. As discussed above, the EVES domain is but one component of the c-Myb negative regulatory domain, although several types of circumstantial evidence support the idea that Myb proteins can exist in both active and inactive conformations. For example, changes in phosphorylation can affect c-Myb DNA binding (Lüscher et al. 1990; Aziz et al. 1993, 1995; Oelgeschläger et al. 1995), and point mutations in a potential hinge region of Myb can cause changes in electrophoretic mobility (Dini et al. 1995) and transcriptional activity (Chen and Lipsick 1993). Besides Myb, several other transcription factors have been shown to undergo conformational changes. For example, DNA binding causes structural changes in the c-Ets protein (Petersen et al. 1995; Jonsen et al. 1996), and the nuclear localization and DNA-binding activity of steroid hormone receptors is regulated by the conformation of their ligand binding domains (for review, see Parker 1993; Truss and Beato 1993). However, the proposed model of c-Myb regulation, in which a negative regulatory domain at the carboxyl terminus competes for the binding of a cellular cofactor to the amino terminus, is a novel one.

Our data predict that overexpression of the c-Myb carboxyl terminus, including the EVES domain, should affect the activity of Myb in trans. Two different laboratories reported such experiments, with quite contradictory results. In one case, overexpression of the c-Myb carboxyl terminus was found to inhibit the activity of cor v-Myb proteins (Dubendorff et al. 1992). In the second case, overexpression of a Myb carboxy-terminal domain stimulated the transcriptional activity of hybrid proteins in which the GAL4 DNA-binding domain was fused to a variety of heterologous trans-activation domains, including one from c-Myb (Vorbrueggen et al. 1994). Both studies identified the same EVES motif-containing active region of the carboxyl terminus, but both concluded that the carboxyl terminus affected the Myb trans-activation domain, rather than the DNA-binding domain. Interestingly, several types of evidence suggest that the Myb trans-activation domain may have a complex function. For example, although specific domains from both
Myb and VP16 will activate transcription, only the latter can interact directly with components of the basal transcription machinery (Frampton et al. 1993). Furthermore, replacing the trans-activation domain from $\mathrm{v}-\mathrm{Myb}$ with the equivalent region of VP16 produces a protein that efficiently activates reporter genes in both animal cells and yeast (Ibanez and Lipsick 1990; Chen and Lipsick 1993) but that no longer transforms (Engelke et al. 1995). Also, mutations that increase v-Myb's ability to activate transcription (as much as 25 -fold) can impair its transformation activity (Lane et al. 1990; Chen and Lipsick 1993). The Myb trans-activation domain was recently found to interact with the transcriptional coactivator CREB-binding protein $(\mathrm{CBP})$, and this interaction is required for the ability of Myb to activate gene expression (Dai et al. 1996; Oelgeschläger et al. 1996). It will be interesting to determine whether $\mathrm{p} 100$ affects this interaction.

\section{Is p100 an activator or an inhibitor?}

Although p100 was first described as a ubiquitously expressed transcriptional coactivator (Tong et al. 1995), ectopic overexpression of the protein led to decreased activity of c-Myb. If p100 is a coactivator for Myb, then our results suggest that it is not limiting in the cells we used. Inhibition of Myb activity presumably occurred in the transfected cells when pl00 was so vastly overexpressed that it bound to and sequestered other, limiting cellular factors. Alternatively, despite the fact that p100 serves as a coactivator for the EBNA-2 protein (Tong et al. 1995), it could be an inhibitor of Myb. A diverse and growing set of eukaryotic transcription factors can function as both transcriptional inhibitors and activators, depending on the context. Examples of these are the vertebrate proteins YY1 and WT1 (Natesan and Gilman 1995; Reddy et al. 1995), the herpes simplex virus protein ICP4 (Gu et al. 1995), and the yeast transcription factor MIG1 (Treitel and Carlson 1995). Even Myb can act as a transcriptional inhibitor in some situations (Mizuguchi et al. 1995). Res olution of this issue will require more detailed investigations of the role of p100 in Myb function, the use of p100 null cell lines or regulatable versions of p100, or in vitro-reconstituted transcription systems, all of which we are currently pursuing.

\section{Materials and methods}

Yeast two-hybrid assays

The yeast strains, expression vectors, and reporter plasmids were kindly provided by R. Brent, R. Finley and co-workers, and have been described elsewhere (Golemis and Brent 1992; Gyuris et al. 1993; Zervos et al. 1993; Estojak et al. 1995). Briefly, bait molecules were constructed by transferring fragments of $\mathrm{Myb}$ or p100 cDNA clones to plasmid pEG202 $\left(2 \mu, \mathrm{HIS}^{+}{ }^{+}, \mathrm{Amp}^{\mathrm{r}}\right.$; Estojak et al. 1995). The resulting bait proteins are fused to amino acids 1-202 of LexA and are expressed from the constitutive ADH1 promoter. All of the bait constructs were tested to make sure that they were transcriptionally inert, but encoded, proteins that could bind DNA in vivo (Golemis and Brent 1992). 
Except where otherwise noted, interacting target proteins were derived from cDNAs expressed under the control of the inducible GAL1 promoter from plasmid pIG4-5 $\left\{2 \mu, T R P 1^{+}, A m p^{r}\right.$; Gyuris et al. 1993; Estojak et al. 1995). The resulting proteins were fused at their amino termini to the influenza virus $\mathrm{HAl}$ epitope tag, the B42 acidic activation domain, and the SV40 nuclear localization signal. The yeast strain EGY48 (MATa trp1 ura3 his3 LEU2:: pLexAop6-LEU2) was used as a host for all two-hybrid assays (Golemis and Brent 1992; Zervos et al. 1993; Estojak et al. 1995). This strain has an integrated LEU2 gene that can be activated by LexA fusion proteins and also contains the reporter plasmid pSH18-34, a $2 \mu$-based reporter construct with a selectable $U R A 3^{+}$marker and a LexA-inducible lacZ gene (Estojak et al. 1995). $\beta$-Galactosidase activity was measured by growing yeast on plates containing the chromogenic substrate X-gal. Alternatively, liquid assays were performed on extracts of yeast grown to mid-log phase (Brent and Ptashne 19851.

\section{Plasmids and DNA manipulations}

Fragments of the chicken c-myb (Gerondakis and Bishop 1986), Xenopus laevis c-myb (Amaravadi and King 1994) or human pl00 (Tong et al. 1995) cDNAs were generated by appropriate restriction enzyme digests or specific PCRs using standard methods. Where necessary, PCR primers were designed with extensions to add specific restriction enzyme sites for cloning. For example, all fragments used for production of bait molecules were designed to have 5' EcoRI and 3 ' Xhol sites, respectively, so that the resulting reading frames matched that of LexA. The integrity of all recombinant DNA molecules was verified by dideoxy sequencing, and the sizes of all generated proteins were verified by using Western blots developed with antibodies directed against Myb or included epitope tags, as appropriate. Plasmid pRFHM1, which expresses a LexA-Bicoid fusion containing residues 2-160 of the Drosophila bicoid gene product fused to amino acids 1-202 of LexA, was obtained from Roger Brent (Harvard University, Cambridge, MA). The yeast plasmid pYGdGE, which expresses a full-length version of the AMV $\mathrm{v}$-Myb protein under control of the galactose-inducible GAL1 promoter (Chen and Lipsick 1993), was provided by J. Lipsick (Stanford University, Palo Alto, CA). Plasmid pSG5-pl00 (Tong et al. 1995) has a strong CMV/T7 promoter for efficient expression of the full-length human pl00 cDNA. The plasmid / which was kindly provided by $\mathrm{X}$. Tong, Harvard University, Cambridge, MA/ was constructed so that the 100 protein would be fused to an amino-terminal FLAG epitope tag. Full-length and truncated versions of the chicken $c-m y b$ cDNA were transferred into the eukaryotic expression vectors pCDNA-1 or pCDNA-3 (Invitrogen), which also have CMV/T7 promoters.

To make the $\triangle$ EVES mutant of pl00, the $3^{\prime}$ end of the p100 cDNA was amplified using pSG5-p100 as template in a PCR reaction using the following primers: 5 '-TAAGAATTCGGCGCCAACCTGTCCGTCCTG-3' and 5'-TGAGCGAGGAAGCGGAAGAG- $3^{\prime}$. The resulting fragment was digested with $E c o R I$ and $X b a I$ and cloned into the mammalian expression vector pCDNA3 (Invitrogen). Next, the 5' end of the p100 cDNA was amplified in the same way using the following primers: 5'-TAATACGACTCACTATAGGG-3' and 5'-TAAGAATTCGCCTCTGGGGCATTCAA-3'. The resulting fragment was digested with EcoRI and cloned into the vector containing the other half of the cDNA. The resulting $\triangle E V E S$ version of $\mathrm{p} 100$ has amino acids 539-589 replaced by two novel amino acids, EF, endoded by an inserted EcoRI site. All constructs were verified by DNA sequencing.

\section{Yeast extracts}

Cultures of yeast $(500 \mathrm{ml})$ were grown to mid-log phase $\left.1 \mathrm{OD}_{600}=0.8\right)$, and cells were collected by centrifugation $(5 \mathrm{~min}$ at $4000 \mathrm{~g}$ / washed once with ice-cold deionized water, and resuspended in $2.5 \mathrm{ml}$ of lysis buffer $(20 \mathrm{~mm}$ HEPES, $5 \mathrm{~mm}$ EDTA, $10 \mathrm{~mm}$ DTT, $10 \%$ glycerol, $100 \mathrm{~mm} \mathrm{KCl}, 1 \mathrm{~mm}$ PMSF, $2 \mu \mathrm{g} / \mathrm{ml}$ of leupeptin, $2 \mu \mathrm{g} / \mathrm{ml}$ of antipain, $1 \mu \mathrm{g} / \mathrm{ml}$ of pepstatin $\mathrm{A}$, and 1 $\mu \mathrm{g} / \mathrm{ml}$ of chymostatin at $\mathrm{pH} 7.91$. The cell suspension was mixed with 5 grams of glass beads and homogenized vigorously for $15 \mathrm{~min}$ at $4^{\circ} \mathrm{C}$ using a vortex mixer. The debris was removed by centrifugation at $4^{\circ} \mathrm{C}$, first at moderate speed $(20 \mathrm{~min}$ at $10,000 \mathrm{~g})$, and then at high speed $\left(250,000 \mathrm{~g}\right.$ for $2 \mathrm{hr}$ at $\left.4^{\circ} \mathrm{C}\right)$. The resulting supernatant was used immediately for immunoprecipitation assays or Western blots, or was flash-frozen in liquid nitrogen and stored at $-80^{\circ} \mathrm{C}$.

\section{Immunoprecipitation and Western blotting assays}

Extracts were incubated with either polyclonal anti-Myb antisera (rabbit antisera PB84, directed against amino acids 72-192 of chicken c-Myb/ or preimmune sera at $0^{\circ} \mathrm{C}$ for $1 \mathrm{hr}$. The antigenantibody complexes were incubated for $30 \mathrm{~min}$ with protein A-Sepharose CL4B (Pharmacia), and complexes were collected by centrifugation and washed three times with cold wash buffer (20 mM HEPES, $5 \mathrm{~mm}$ EDTA, $100 \mathrm{~mm} \mathrm{KCl}, 10 \mathrm{~mm}$ DTT, $1 \mathrm{~mm}$ PMSF, $2 \mu \mathrm{g} / \mathrm{ml}$ of leupeptin, $2 \mu \mathrm{g} / \mathrm{ml}$ of antipain, $1 \mu \mathrm{g} / \mathrm{ml}$ of pepstatin $\mathrm{A}$, and $1 \mu \mathrm{g} / \mathrm{ml}$ of chymostatin at $\mathrm{pH} 7.91$. A final wash included centrifugation through a cushion of the same buffer supplemented with $30 \%$ sucrose. The complexes were resuspended in SDS-PAGE sample buffer, heated at $95^{\circ} \mathrm{C}$ for 3 min, and separated on 15\% SDS-polyacrylamide gels (Ness et al. 1989). For Western blots, the fractionated proteins were transferred onto PVDF membranes (Millipore) using an electroblotting apparatus (Genie Scientific). Precipitated proteins were detected using mouse antibodies specific for chicken c-Myb (mAb 173 specific for amino acids 72-192 of chick $\mathrm{c}-\mathrm{Myb}$ ) or the epitope tag derived from influenza virus HA protein (kindly provided by R.A. Lamb, Northwestern University, Evanston, IL). The blots were developed using the ECL Chemiluminescence assay system (Amersham).

In vitro transcription/translation of p100 or Myb proteins was performed using expression plasmids having $\mathrm{T} 7$ or $\mathrm{CMV} / \mathrm{T} 7$ promoters and a coupled T7 RNA polymerase/reticulocyte lysate expression system (Promega) supplemented with $\left[{ }^{35} \mathrm{~S} \mid \mathrm{me}\right.$ thionine. For pulldown assays, extracts were mixed and incubated on ice for $30 \mathrm{~min}$ and divided into three equal fractions for subsequent immunoprecipitation with antisera specific for $\mathrm{Myb}$ or the FLAG epitope tag as described above, except that all wash buffers were adjusted to $0.3 \mathrm{M} \mathrm{KCl}$. The immunoprecipitates were fractionated by SDS-PAGE, and proteins were detected by Western blotting (ECL, Amersham), fluorography (ENTENSIFY, Dupont), or PhosphorImaging (FUJIX BAS1000), as appropriate.

\section{Nuclear extracts}

The human Jurkat T-cell line was maintained in RPMI medium supplemented with $10 \%$ fetal bovine serum. Nuclear extracts were prepared by standard methods, using ice-cold buffers supplemented with $10 \mathrm{~mm}$ dithiothreitol (DTT), $1 \mathrm{~mm}$ phenylmethylsulfonylflouride (PMSF), $2 \mu \mathrm{g} / \mathrm{ml}$ each of leupeptin and antipain, and $1 \mu \mathrm{g} / \mathrm{ml}$ each of pepstatin-A and chymotrypsin throughout. Briefly, cells were collected by centrifugation, rinsed once with ice-cold phosphate-buffered saline (PBS), resuspended, and allowed to lyse for $10 \mathrm{~min}$ on ice in homogenization buffer (20 mM HEPES, $5 \mathrm{~mm}$ EDTA) containing $0.5 \%$ 
NP-40. The nuclei were collected by centrifugation for $10 \mathrm{~min}$ at $8000 \mathrm{rpm}$ in a Sorvall SS-34 rotor, resuspended in the same buffer containing $0.1 \%$ NP-40 using a Dounce homogenizer, and collected by centrifugation as before. The washed nuclei were extracted by homogenizing as before, using higher ionic strength buffer $(20 \mathrm{~mm}$ HEPES, $5 \mathrm{~mm}$ EDTA, $0.3 \mathrm{M} \mathrm{KCl}$, plus supplements described abovel. The final extract was cleared of debris with a 5 -min centrifugation at $100,000 \mathrm{~g}$ in a Beckman TL-100 benchtop ultracentrifuge.

\section{Data base searches and sequence alignments}

Residues 513-563 of the chicken c-Myb protein were compared to all available protein sequences in the following data bases: Brookhaven Protein Data Bank (April 1995 release), SWISSPROT release 32.0 , PIR release 47.0 , and the CDS translations from GenBank(R) release 93. The computation was performed at the NCBI using the BLAST network service. Alignments between Myb and pl00 proteins were performed using the Bestfit and Pileup program components of the Wisconsin Genetics Computer Group package, running on a Silicon Graphics Challenge L Workstation using IRIX 5.2.

\section{Transfection assays}

Transient transfection assays with QT6 cells were performed using routine DEAE-dextran methods, as described previously (Ness et al. 1989, 1993). The mim-1 gene promoter-reporter construct, which extends to -242 nucleotides relative to the major transcription start site, has been described and contains binding sites for both Myb and NF-M (Ness et al. 1989, 1993). The expression plasmids for NF-M and p100 have been described (Katz et al. 1993; Ness et al. 1993; Tong et al. 1995). The c-Myb expression plasmid pCMV-Myb was generated by transferring a BamHI fragment containing the chicken c-Myb cDNA (Gerondakis and Bishop 1986) to the eukaryotic expression vector pCDNA1 (Invitrogen).

\section{Acknowledgments}

We are especially grateful to X. Tong and E. Kieff for sharing plasmids and information prior to publication. We also thank K.-H. Klempnauer, J. Lipsick, and M.W. King for kindly providing various chicken and frog c-Myb expression plasmids; $R$. Brent, R. Finley, and co-workers for providing the yeast twohybrid system components; Yi Shen and Guihua Sun, who provided expert technical assistance; and our colleagues $\mathrm{A}$. Wandinger-Ness, R.F. Gaber, and R.A. Lamb for sharing equipment, help with yeast methods and assays, and HA-specific antibodies, respectively. Partial support for F.C.O. was provided by a National Institutes of Health Training Grant on the Cellular and Molecular Basis of Disease (T32 GM08061). This research was supported by grants to S.A.N. from the U.S. Public Health Service National Cancer Institute (RO1 CA58443), The Council for Tobacco Research, Inc. (3849), and NATO (921331), as well as by short-term grants from The Leukemia Research Foundation and American Cancer Society, Illinois Division.

The publication costs of this article were defrayed in part by payment of page charges. This article must therefore be hereby marked "advertisement" in accordance with 18 USC section 1734 solely to indicate this fact.

\section{References}

Altschul, S.F., W. Gish, W. Miller, E.W. Myers, and D.J. Lipman. 1990. Basic local alignment search tool. I. Mol. Biol. 215: $403-410$.
Amaravadi, L. and M.W. King. 1994. Characterization and expression of the Xenopus c-Myb homolog. Oncogene 9: 971974.

Aziz, N., J. Wu, J.W. Dubendorff, J.S. Lipsick, T.W. Sturgill, and T.P. Bender. 1993. c-Myb and v-Myb are differentially phosphorylated by p42mapk in vitro. Oncogene 8: 2259-2265.

Aziz, N., M.R. Miglarese, R.C. Hendrickson, J. Shabanowitz, T.W. Sturgill, D.F. Hunt, and T.P. Bender. 1995. Modulation of c-Myb-induced transcription activation by a phosphorylation site near the negative regulatory domain. Proc. Natl. Acad. Sci. 92: 6429-6433.

Bies, J., R. Mukhopadhyaya, J. Pierce, and L. Wolff. 1995. Only late, nonmitotic stages of granulocyte differentiation in $32 \mathrm{Dcl} 3$ cells are blocked by ectopic expression of murine c-myb and its truncated forms. Cell Growth Differ. 6: 59-68.

Bishop, J.M. 1991. Molecular themes in oncogenesis. Cell 64: 35-248.

Bortner, D.M. and M.C. Ostrowski. 1991. Analysis of the v-myb structural components important for transactivation of gene expression. Nucleic Acids Res. 19: 1533-1539.

Brent, R. and M. Ptashne. 1985. A eukaryotic transcriptional activator bearing the DNA specificity of a prokaryotic repressor. Cell 43: 729-736.

Burk, O., S. Mink, M. Ringwald, and K.-H. Klempnauer. 1993. Synergistic activation of the chicken mim-1 gene by v-myb and C/EBP transcription factors. EMBO J. 12: 2027-2038.

Chen, R.-H. and J.S. Lipsick. 1993. Differential Transcriptional Activation by v-Myb and c-Myb in animal cells and Saccharomyces cervisiae. Mol. Cell. Biol. 13: 4423-4431.

Clarke, M.F., J.F. Kukowska-Latallo, E. Westin, M. Smith, and E.V. Prochownik. 1988. Constitutive expression of a c-myb cDNA blocks friend murine erythroleukemia cell differentiation. Mol. Cell. Biol. 8:1884-892.

Dai, P., H. Akimaru, Y. Tanaka, D.-X. Hou, T. Yasukawa, C. Kanei-Ishii, T. Takahashi, and S. Ishii. 1996. CBP as a transcriptional coactivator of c-Myb. Genes \& Dev. 10: 528-540.

Dini, P.W. and J.S. Lipsick. 1993. Oncogenic truncation of the first repeat of $\mathrm{c}-\mathrm{Myb}$ decreases DNA binding in vitro and in vivo. Mol. Cell. Biol. 13: 7334-7348.

Dini, P.W., J.T. Eltman, and J.S. Lipsick. 1995. Mutations in the DNA-binding and transcriptional activation domains of v-Myb cooperate in transformation. I. Virol. 69: 2515-2524.

Dubendorff, J.W., L.J. Whittaker, J.T. Eltman, and J.S. Lipsick. 1992. Carboxy-terminal elements of c-Myb negatively regulate transcriptional activation in cis and in trans. Genes \& Dev. 6: 2524-2535.

Engelke, U., L. Whittaker, and J.S. Lipsick. 1995. Weak transcriptional activation is sufficient for transformation by v-Myb. Virology 208: 467-477.

Estojak, J., R. Brent, and E.A. Golemis. 1995. Correlation of two-hybrid affinity data with in vitro measurements. Mol. Cell. Biol. 15: 5820-5829.

Favier, D. and T.J. Gonda. 1994. Detection of proteins that bind to the leucine zipper motif of c-Myb. Oncogene 9: 305-311.

Ferrao, P., E.M. Macmillan, L.K. Ashman, and T.J. Gonda. 1995. Enforced expression of full length c-Myb leads to densitydependent transformation of murine haemopoietic cells. Oncogene 11: 1631-1638.

Fields, S. and O. Song. 1989. A novel genetic system to detect protein-protein interactions. Nature 340: 245-246.

Frampton, J., A. Leutz, T. Gibson, and T. Graf. 1989. DNA binding domain ancestry. Nature 342: 134.

Frampton, J., T. Kouzarides, G. Doderlein, T. Graf, and K. Weston. 1993. Influence of the $\mathrm{v}-\mathrm{Myb}$ transactivation domain on the oncoprotein's transformation specificity. $E M B O$ f. 12: 1333-1341. 
Furuta, Y., S. Aizawa, Y. Suda, Y. Ikawa, H. Nakasgoshi, Y. Nishina, and S. Ishii. 1993. Degeneration of skeletal and cardiac muscles in c-myb transgenic mice. Transgen. Res. 2: 199-207.

Garcia, A., K. LaMontagne, D. Reavis, U. Stober-Grasser, and J.S. Lipsick. 1991. Determinants of sequence-specific DNAbinding by $\mathrm{p}^{\mathrm{v}-\mathrm{myb}}$. Oncogene 6: 265-273.

Gerondakis, S. and J.M. Bishop. 1986. Structure of the protein encoded by the chicken proto-oncogene c-myb. Mol. Cell. Biol. 6: 3677-3684.

Golay, J., A. Capucci, M. Arsura, M. Castellano, V. Rizzo, and M. Introna. 1991. Expression of c-myb and B-myb, but not A-myb, correlates with proliferation in human hematopoietic cells. Blood 77: 149-158.

Golemis, E.A. and R. Brent. 1992. Fused protein domains inhibit DNA binding by LexA. Mol. Cell. Biol. 12: 3006-3014.

Gonda, T.J., C. Buckmaster, and R.G. Ramsay. 1989a. Activation of c-myb by carboxy-terminal truncation: Relationship to transformation of murine haemopoietic cells in vitro. $E M B O$ I. 8: 1777-1783.

Gonda, T.J., R.G. Ramsay, and G.R. Johnson. 1989b. Murine myeloid cell lines derived by in vitro infection with recombinant c-myb retroviruses express myb from rearranged vector proviruses. EMBO J. 8: 1767-1175.

Grässer, F.A., T. Graf, and J. Lipsick. 1991. Protein truncation is required for the activation of the c-myb proto-oncogene. Mol. Cell. Biol. 11: 3987-3996.

Gu, B., R. Kuddus, and N.A. DeLuca. 1995. Repression of activator-mediated transcription by herpes simplex virus ICP4 via a mechanism involving interactions with the basal transcription factors TATA-binding protein and TFIIB. Mol. Cell. Biol. 15: 3618-3626.

Gyuris, J., E. Golemis, H. Chertkov, and R. Brent. 1993. Cdil, a human Gl and $S$ phase protein phosphatase that associates with Cdk2. Cell 75: 791-803.

Howe, K.M., C.F.L. Reakes, and R.J. Watson. 1990. Characterization of the sequence-specific interaction of mouse c-myb protein with DNA. EMBO I. 9: 161-169.

Hu, Y., R.G. Ramsay, C. Kanei-Ishii, S. Ishii, and T.J. Gonda. 1991. Transformation by carboxyl-deleted Myb reflects increased transactivating capacity and disruption of a negative regulatory domain. Oncogene 6: 1549-1551.

Ibanez, C.E. and J.S. Lipsick. 1990. trans-Activation of gene expression by v-myb. Mol. Cell. Biol. 10: 2285-2293.

Introna, M., J. Golay, J. Frampton, T. Nakano, S.A. Ness, and T. Graf. 1990. Mutations in v-myb alter the differentiation of myelomonocytic cells transformed by the oncogene. Cell 63: 1287-1297.

Jonsen, M.D., J.M. Petersen, Q.-P. Xu, and B.J. Graves. 1996. Characterization of the cooperative function of inhibitory sequences in Ets-1. Mol. Cell. Biol. 16: 2065-2073.

Kanei-Ishii, C., E.M. MacMillan, T. Nomura, A. Sarai, R.G. Ramsay, S. Aimoto, S. Ishii, and T.J. Gonda. 1992. Transactivation and transformation by $\mathrm{Myb}$ are negatively regulated by a leucine-zipper structure. Proc. Natl. Acad. Sci. 89: 3088-3092.

Katz, S., E. Kowenz-Leutz, C. Müller, K. Meese, S.A. Ness, and A. Leutz. 1993. The NF-M transcription factor is related to $\mathrm{C} / \mathrm{EBP} \beta$ and plays a role in signal transduction, differentiation and leukemogenesis of avian myelomonocytic cells. $E M B O$ J. 12: 1321-1332.

Lane, T.N., C.E. Ibanez, A. Garcia, T. Graf, and J.S. Lipsick. 1990. Transformation by v-myb correlates with trans-activation of gene expression. Mol. Cell. Biol. 10: 2591-2598.

Lüscher, B., E. Christenson, D.W. Litchfield, E.G. Krebs, and R.N. Eisenman. 1990. Myb DNA binding inhibited by phos- phorylation at a site deleted during oncogenic activation. Nature 344: 517-522.

McClinton, D., I. Stafford, L. Brents, T.P. Bender, and W.M. Kuehl. 1990. Differentiation of mouse erythroleukemia cells is blocked by late up-regulation of a c-myb transgene. Mol. Cell. Biol. 10: 705-710.

Mizuguchi, G., C. Kanei-Ishii, T. Takahashi, T. Yasukawa, T. Nagase, M. Horikoshi, T. Yamamoto, and S. Ishii. 1995. c-Myb repression of c-erbB- 2 transcription by direct binding to the c-erbB-2 promoter. I. Biol. Chem. 270: 9384-9389.

Mukhopadhyaya, R. and L. Wolff. 1992. New sites of proviral integration associated with murine promonocytic leukemias and evidence for alternate modes of c-myb activation. $J$. Virol. 66: 6035-6044.

Nason-Burchenal, K. and L. Wolff. 1993. Activation of c-myb is an early bone-marrow event in a murine model for acute promonocytic leukemia. Proc. Natl. Acad. Sci. 90: 16191623.

Natesan, S. and M. Gilman. 1995. YYl facilitates the association of serum response factor with the c-fos serum response element. Mol. Cell. Biol. 15: 5975-5982.

Ness, S.A., A. Marknell, and T. Graf. 1989. The v-myb oncogene product binds to and activates the promyelocyte-specific mim-1 gene. Cell 59: 1115-1125.

Ness, S.A., E. Kowenz-Leutz, T. Casini, T. Graf, and A. Leutz. 1993. Myb and NF-M: Combinatorial activators of myeloid genes in heterologous cell types. Genes \& Dev. 7: 749-759.

Ness, S.A. 1996. The Myb Oncoprotein: Regulating a regulator. Biochem. Biophys. Acta Rev. Cancer. (in press).

Nomura, N., M. Takahashi, M. Matsui, S. Ishii, T. Date, S. Shigemi, and R. Ishizaki. 1988. Isolation of human cDNA clones of myb-related genes, A-myb and B-myb. Nucleic Acids Res. 16: 11075-11089.

Nomura, T., N. Sakai, A. Sarai, T. Sudo, I.C. Kanei, R.G. Ramsay, D. Favier, T.J. Gonda, and S. Ishii. 1993. Negative autoregulation of c-Myb activity by homodimer formation through the leucine zipper. I. Biol. Chem. 268: 21914 21923.

Oelgeschläger, M., J. Krieg, J.M. Lüscher-Firzlaff, and B. Lüscher. 1995. Casein kinase II phosphorylation site mutations in $\mathrm{c}-\mathrm{Myb}$ affect DNA binding and transcriptional cooperativity with NF-M. Mol. Cell. Biol. 15: 5966-5974.

Oelgeschläger, M., R. Janknecht, J. Krieg, S. Schreek, and B. Lüscher. 1996. Interaction of the co-activator CBP with Myb proteins: Effects on the Myb-specific transcription and on the cooperativity with NF-M. EMBO /. 15: 2771-2780.

Ogata, K., H. Kanai, T. Inoue, A. Sekikawa, M. Sasaki, A. Nagadoi, A. Sarai, S. Ishii, and Y. Nishimura. 1993. Solution structures of Myb DNA-binding domain and its complex with DNA. Nucleic Acids Symp. Ser. 29: 201-202.

Ogata, K., S. Morikawa, H. Nakamura, A. Sekikawa, T. Inoue, H. Kanai, A. Sarai, S. Ishii, and Y. Nishimura. 1994. Solution structure of a specific DNA complex of the Myb DNA-binding domain with cooperative recognition helices. Cell 79: 639-648.

Parker, M.G. 1993. Steroid and related receptors. Curr. Opin. Cell Biol. 5: 499-504.

Petersen, I.M., J.J. Skalicky, L.W. Donaldson, L.P. McIntosh, T. Alber, and B.J. Graves. 1995. Modulation of transcription factor Ets-1 DNA binding: DNA-induced unfolding of an alpha helix. Science 269: 1866-1869.

Ramachandran, S., K. Hiratsuka, and N.H. Chua. 1994. Transcription factors in plant growth and development. Curr. Opin. Genet. Dev. 4: 642-646.

Ramsay, R.G., S. Ishii, and T.J. Gonda. 1991. Increase in specific DNA binding by carboxyl truncation suggests a mechanism 
for activation of Myb. Oncogene 6: 1815-1819.

Reddy, J.C., S. Hosono, and J.D. Licht. 1995. The transcriptional effect of WT1 is modulated by choice of expression vector. J. Biol. Chem. 270: 29976-29982.

Sakura, H., C. Kanai-Ishii, T. Nagase, H. Nakagoshi, T.J. Gonda, and S. Ishii. 1989. Delineation of three functional domains of the transcriptional activator encoded by the c-myb protooncogene. Proc. Natl. Acad. Sci. 86: 5758-5762.

Selvakumaran, M., D.A. Liebermann, and B. Hoffman-Liebermann. 1992. Deregulated c-myb disrupts interleukin-6 or leukemia inhibitory factor-induced myeloid differentiation prior to c-myc: Role in leukemogenesis. Mol. Cell. Biol. 12: 2493-2500.

Shen-Ong, G.L.C., M. Potter, J.F. Mushinski, S. Lavu, and E.P. Reddy. 1984. Activation of the c-myb locus by viral insertinal mutagenesis in plasmacytoid lymphosarcomas. Science 226: $1077-1080$.

Shen-Ong, G.L.C., H.C. Morse III, M. Potter, and F. Mushinski. 1986. Two modes of c-myb activation in virus-induced mouse myeloid tumors. Mol. Cell. Biol. 6: 380-392.

Sleeman, J.P. 1993. Xenopus A-myb is expressed during early spermatogenesis. Oncogene 8: 1931-1941.

Smarda, J. and J.S. Lipsick. 1994. c-Myb prevents TPA-induced differentiation and cell death in v-Myb transformed monoblasts. Oncogene 9: $237-245$.

Todokoro, K., R.J. Watson, H. Higo, H. Amanuma, S. Kuramochi, H. Yanagisawa, and Y. Ikawa. 1988. Down-regulation of c-myb gene expression is a prerequisite for erythropoietininduced erythroid differentiation. Proc. Natl. Acad. Sci. 85: 8900-8904.

Tong, X., R. Drapkin, R. Yalamanchili, G. Mosialos, and E. Kieff. 1995. The Epstein-Barr virus nuclear protein 2 acidic domain forms a complex with a novel cellular coactivator that can interact with TFIIE. Mol. Cell. Biol. 15: 4735-4744.

Trauth, K., B. Mutschler, N.A. Jenkins, D.J. Gilbert, N.G. Copeland, and K.H. Klempnauer. 1994. Mouse A-myb encodes a trans-activator and is expressed in mitotically active cells of the developing central nervous system, adult testis and B lymphocytes. EMBO /. 13: 5994-6005.

Treitel, M.A. and M. Carlson. 1995. Repression by SSN6-TUP1 is directed by MIG1, a repressor/activator protein. Proc. Natl. Acad. Sci. 92: 3132-3136.

Truss, M. and M. Beato. 1993. Steroid hormone receptors: interaction with deoxyribonucleic acid and transcription factors. Endocrine Rev. 14: 459-479.

Vorbrueggen, G., F. Kalkbrenner, S. Guehmann, and K. Moelling. 1994. The carboxy terminus of human c-myb protein stimulates activated transcription in trans. Nucleic Acids Res. 22: 2466-2475.

Weston, K. and J.M. Bishop. 1989. Transcriptional activation by the v-myb oncogene and its cellular progenitor, c-myb. Cell 58: 85- -93 .

Yanagisawa, H., T. Nagasawa, S. Kuramochi, T. Abe, Y. Ikawa, and K. Todokoro. 1991. Constitutive expression of exogenous c-myb gene causes maturation block in monocyte-macrophage differentiation. Biochim. Biophys. Acta 1088: 380384.

Zervos, A.S., J. Gyuris, and R. Brent. 1993. Mxil, a protein that specifically interacts with Max to bind Myc-Max recognition sites. Cell 72: 223-232. 


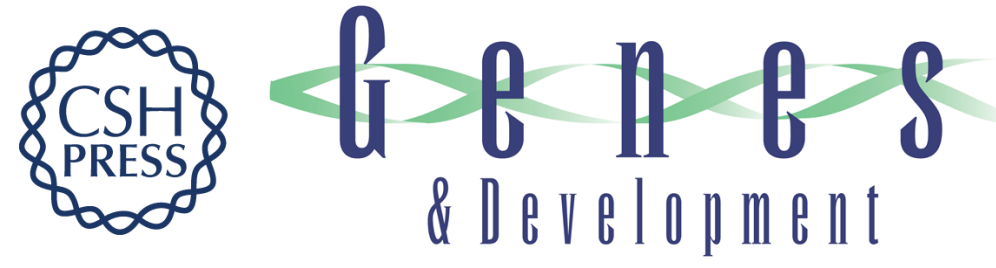

\section{The EVES motif mediates both intermolecular and intramolecular regulation of c-Myb.}

A B Dash, F C Orrico and S A Ness

Genes Dev. 1996, 10:

Access the most recent version at doi:10.1101/gad.10.15.1858

References This article cites 73 articles, 34 of which can be accessed free at:

http://genesdev.cshlp.org/content/10/15/1858.full.html\#ref-list-1

License

Email Alerting

Service

Receive free email alerts when new articles cite this article - sign up in the box at the top right corner of the article or click here.

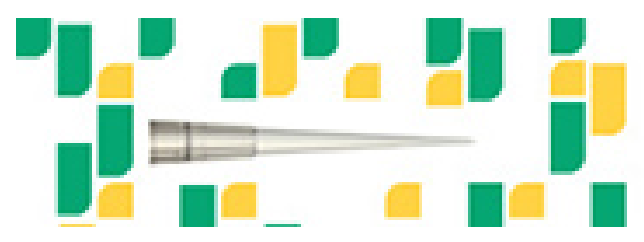

Focused on your science.

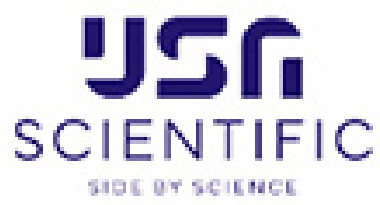

Copyright (c) Cold Spring Harbor Laboratory Press 